\title{
Visceral Tissue Mass and Rumen Volume in Dairy Cows During the Transition from Late Gestation to Early Lactation
}

\author{
C. K. Reynolds, ${ }^{\star}$ B. Dürst,† B. Lupoli, D. J. Humphries, and D. E. Beever \\ Centre for Dairy Research, \\ Department of Agriculture \\ The University of Reading \\ Earley Gate \\ Reading RG6 6AT England
}

\section{ABSTRACT}

The objectives were to measure the effects of transition and supplemental barley or rumen-protected protein on visceral tissue mass in dairy cows and the effects of transition and barley on rumen volume and liquid turnover. Cows were individually fed a grass silagebased gestation ration to meet energy and protein requirements for body weight stasis beginning 6 wk before expected calving. A corn silage-based lactation ration was individually fed ad libitum after calving. In the visceral mass study, 36 cows were randomly assigned to one of 3 dietary treatments: basal ration or basal ration plus either $800 \mathrm{~g}$ dry matter (DM) of barley meal per day or $750 \mathrm{~g}$ DM of rumen-protected soybean protein per day. Cows were slaughtered at 21 and $7 \mathrm{~d}$ before expected calving date or at 10 and $22 \mathrm{~d}$ postpartum. Visceral mass and rumen papillae characteristics were measured. Diets had little effect on visceral mass. The mass of the reticulo-rumen, small intestine, large intestine, and liver was, or tended to be, greater at $22 \mathrm{~d}$ postpartum but not at $10 \mathrm{~d}$ postpartum before DM intake had increased. Rumen papillae mass increased at $10 \mathrm{~d}$ postpartum, perhaps in response to increased concentrates. Mesenteric fat decreased after calving, reflecting body fat mobilization. Ten rumen-cannulated cows were fed the basal gestation ration alone or supplemented with $880 \mathrm{~g}$ of barley meal DM. Rumen volumes and liquid dilution rates were measured at 17 and $8 \mathrm{~d}$ before calving and at 10,20 , and $31 \mathrm{~d}$ postpartum. Feeding barley had no effects. After calving, rumen DM volume and liquid dilution rate increased, but liquid volume did not increase. Changes in gastrointestinal

Received May 14, 2003.

Accepted September 23, 2003.

Corresponding author: C. K. Reynolds; e-mail: reynolds. 345@osu.edu.

*Current address: Department of Animal Sciences, The Ohio State University, OARDC, Wooster, 44696-4076.

$\dagger$ Current address: SLT, Federal Chancellery, 3003 Berne, Switzerland. and liver mass during transition were apparently a consequence of changes in DM intake and nutrient supply and not initiation of lactation per se.

(Key words: viscera, rumen volume, transition, dairy cow)

Abbreviation key: ECD = expected calving date, $\mathbf{M E}=$ metabolizable energy.

\section{INTRODUCTION}

The transition from gestation to peak lactation in high-yielding dairy cows is characterized by coordinated physiological and metabolic adaptations involving numerous tissues (Bell, 1995; Grummer, 1995; Bauman, 2000). As a part of this response, the gastrointestinal tract and liver must increase capacity for diet digestion, nutrient absorption, and synthetic processes to meet the demands of the mammary gland for nutrients and consequent increases in appetite and DMI (Bauman, 2000; Ingvartsen and Andersen, 2000). In sheep, changes in visceral tissue mass in late gestation and lactation were highly correlated with changes in DMI (Fell et al., 1972), but evidence from rats suggests that pregnancy and lactation may induce gut hypertrophy without changes in diet intake (Campbell and Fell, 1964), perhaps through increased placental lactogen, prolactin, or other hormones influencing mammary development (Fell and Weekes, 1975). In the first $8 \mathrm{wk}$ postpartum, tissue mass of the liver, total gut, and total stomach of relatively low yielding cows increased 1,6 , and $4 \mathrm{~kg}$, respectively, whereas the length of the small intestine increased $5 \mathrm{~m}$ (Gibb et al., 1992). Other studies (Bell, 1995) suggest that liver protein synthesis increases as early as $10 \mathrm{~d}$ before calving, supporting the notion that changes in visceral mass and metabolism during transition may be independent of changes in diet intake. The gut and liver have a high maintenance requirement for energy and protein (Johnson et al., 1990), and their growth increases the cow's total nutrient requirements considerably. 
The practice of supplemental feeding before calving, or "steaming up," was widely practiced in the UK in the 1950 s, but it led to concerns about over conditioning. Blaxter (1944) hypothesized that increased milk yield when supplemental feed was provided in late gestation was attributable to the effects of nutrient availability on mammary development before calving, but the changes in the nutrient requirements of other tissues and many other factors are undoubtedly involved (NRC, 2001). In recent years, concerns over depressed intakes of metabolizable energy (ME) and protein in the days near calving, amelioration of fatty liver development at calving, adaptation of rumen microflora to lactation ration concentrates before calving, and the potential benefit of supplemental RUP in late gestation have been the basis of numerous studies about the effects of supplemental carbohydrates and protein in late gestation on subsequent lactation performance (for a partial review see Grummer, 1995; Bell, 1995; NRC, 2001).

Changes in estimated rumen papillae surface area and absorptive capacity in cows changed from a strawbased gestation ration to a high concentrate lactation ration (Dirksen et al., 1985) are an often cited justification for feeding supplemental starch-rich concentrates in late gestation. Supplemental starch may also alter fermentation of the basal ration and thus rumen fill and digesta kinetics during transition. However, in more recent studies substituting barley for forage in the diets of late gestation dairy cows, to increase rumen acid load and alter rumen VFA concentrations, had no effect on rumen papillae characteristics (Andersen et al., 1999) or lactation performance (Ingvartsen et al., 2001). The effects of late pregnancy on visceral tissue mass of cattle are not well defined. Pregnancy and stage of pregnancy had no effect on visceral tissue mass of beef heifers consuming equal $\mathrm{ME}$, but rumen fluid and digesta fill declined as pregnancy progressed (Scheaffer et al., 2001). Transition from late pregnancy to early lactation increased rumen volume in dairy cows (Dann et al., 1999), but transition (Dann et al., 1999) and stage of lactation (Hartnell and Satter, 1979) had no effect on rumen liquid and digesta kinetics.

Feeding supplemental RUP in the dry period has had positive effects on subsequent milk protein concentration in some studies (Van Saun et al., 1993; Moorby et al., 1996), but the response has been inconsistent, and sometimes negative, in other studies (NRC, 2001). There is no question that the protein requirements of the fetus and uterus increase in late gestation, and the studies cited by Bell (1995) suggest the amino acid requirements of visceral tissues may increase as well. By providing more metabolizable protein in late gestation the development of the gut and liver may be enhanced.
Our objectives were to determine whether transition and supplemental concentrate energy (barley) or RUP in late gestation affected visceral tissue mass in dairy cows. In addition, the effect of transition and supplemental barley in late gestation on rumen digesta volume in dairy cows is reported.

\section{MATERIALS AND METHODS}

\section{Visceral Mass Study}

Cows, diets, and treatments. All procedures used were licensed and regulated by the UK Home Office under the Animals (Scientific Procedures) Act of 1986. Thirty-six Holstein $\times$ Friesian cows scheduled for slaughter under the UK Intervention Board Selective Cull Scheme for cohorts of cows diagnosed with bovine spongiform encephalopathy were used. There was no evidence of bovine spongiform encephalopathy observed in any of the cows used for the study. Cows were pastured on perennial ryegrass and provided trace-mineralized salt blocks free choice after finishing their previous lactation. Beginning 6 wk before expected calving date (ECD), they were moved to free-stall housing with grooved concrete floors, sand-bedded cubicles, and constant access to fresh water and trace-mineralized salt blocks for the duration of the study. All animals were offered a control gestation ration (Table 1) to meet $\mathrm{ME}$ and $\mathrm{CP}$ requirements for maintenance and gestation (NRC, 1989) based on their initial BW. As cows began the experiment they were randomly assigned to one of 3 treatments: no supplement (Control; $n=12$ ), the control ration plus supplemental protein $(n=13)$, or the control ration plus supplemental barley meal $(\mathrm{n}=11)$. The supplemental protein was comprised of $750 \mathrm{~g}$ DM per day of rumen-protected soybean protein (Soypass, Borregaard UK, Warrington; $511 \mathrm{~g}$ of $\mathrm{CP}, 74 \mathrm{~g}$ of ash and $17 \mathrm{~g}$ of ether extract/kg DM) fed to increase estimated ration CP content from 120 to $150 \mathrm{~g} / \mathrm{kg}$ DM. Barley (137 $\mathrm{g}$ of CP, $27 \mathrm{~g}$ of ash, $36 \mathrm{~g}$ of ether extract, $204 \mathrm{~g}$ of NDF, and $597 \mathrm{~g}$ of $\mathrm{starch} / \mathrm{kg} \mathrm{DM}$ ) was fed at $800 \mathrm{~g} \mathrm{DM}$ per day to provide the same estimated ME as the supplemental protein. Rations were individually fed daily as a TMR using Calan-Broadbent electronic gates (American Calan Inc., Northwood, NH). Supplements were added as a top-dressing to ensure consumption, and refusals were removed on Monday, Wednesday, and Friday of each week. Beginning $7 \mathrm{~d}$ before ECD, all cows also received $2 \mathrm{~kg}$ of a lactation ration (Table 1), which was offered ad libitum after calving. Cows were housed and fed in individual pens for calving, which were bedded with straw, and provided constant access to fresh water. After calving, cows were returned to the free-stall yard as soon as their recovery allowed, which was normally within $48 \mathrm{~h}$ of calving, and milked twice daily. All cows 
Table 1. Composition of TMR fed during gestation and lactation in the visceral mass study.

\begin{tabular}{lcc}
\hline Composition & Gestation & Lactation \\
\hline Ingredient, g/kg DM & & \\
Chopped barley straw & 250 & \\
Maize silage & 150 & 427 \\
Grass silage & 450 & 143 \\
Soybean meal, 54\% CP & 60 & 59 \\
Dry rolled barley & 80 & \\
Milled wheat & 201 & 101 \\
Rapeseed meal & & 40 \\
Molasses (Regumaize 44) & & 14 \\
Fishmeal & & 6 \\
Fat (Megalac) & & 93 \\
Mineral mix & $10^{2}$ & \\
Composition, g/kg DM & & 446 \\
DM, g/kg as fed & 436 & 2.92 \\
Estimated ME ${ }^{4}$, Mcal/kg DM & 2.70 & 196 \\
CP & 134 & 345 \\
NDF & 493 & 203 \\
ADF & 316 & 35.0 \\
Ether extract & ND & 354 \\
Nonfiber carbohydrate & & \\
\hline
\end{tabular}

${ }^{1}$ SuG Intermol, Marseyside, UK.

${ }^{2}$ Containing (per kg) $138 \mathrm{~g}$ of sodium, $100 \mathrm{~g}$ of phosphorus, $100 \mathrm{~g}$ of magnesium, $15 \mathrm{~g}$ of calcium, $4.5 \mathrm{~g}$ of manganese, $2.5 \mathrm{~g}$ of zinc, 1.5 $\mathrm{g}$ of copper, $300 \mathrm{mg}$ of iodine, $100 \mathrm{mg}$ of cobalt, $15 \mathrm{mg}$ of selenium, $250 \mathrm{IU}$ of vitamin E, 60,000 IU of vitamin D3, and 300,000 IU of vitamin $\mathrm{A}$.

${ }^{3}$ Containing (per kg) $120 \mathrm{~g}$ of phosphorus, $50 \mathrm{~g}$ of magnesium, 180 $\mathrm{g}$ of calcium, $15 \mathrm{mg}$ of selenium, $1500 \mathrm{mg}$ of copper, $550 \mathrm{IU}$ of vitamin $\mathrm{E}, 80 \mathrm{IU}$ of vitamin D3, and $380 \mathrm{IU}$ of vitamin A.

${ }^{4} \mathrm{ME}=$ Metabolizable energy

${ }^{5}$ Not determined.

${ }^{6}$ Vincini et al., 2003.

were individually fed the same ration after calving. Samples of silages and TMR were obtained twice weekly, frozen, and composited monthly for subsequent compositional analysis by a commercial laboratory (Dairy One, Ithaca, NY) as described previously for a separate trial conducted simultaneously at our location (trial 2 of Vicini et al., 2003). Ration components were analyzed for DM content twice weekly to calculate TMR inclusion rates and daily DMI. Body weight and BCS (estimated by the same person using a 5-point scale; Mulvany, 1977) were determined weekly.

Measurement of visceral mass. Cows were scheduled for slaughter at 21 and $7 \mathrm{~d}$ before ECD and 10 and $20 \mathrm{~d}$ after calving. Abattoir facilities and Intervention Board inspectors were not available every day of the week, but each cow was slaughtered as close as possible to her scheduled date. Cows were transported to the Intervention Board approved abattoir (University of Bristol, Langford, UK) the day before slaughter, where they were housed, fed their normal rations, provided water, and milked in straw-bedded box stalls. Before transport, cows were weighed, moved to straw-bedded box stalls after the morning milking, and fed their daily rations. The following morning they were weighed after milking. Then they were walked to the abattoir, where they were euthanized by stunning with a captive bolt pistol, followed by an intravenous injection of barbiturate (Euthatol) to euthanize the fetus of pregnant cows. The body was then dissected much as described by Gibb et al. (1992), except that no attempt was made to quantify gut contents. The following tissues were dissected: reticulo-rumen, omasum, abomasum, small intestine, large intestine, caecum, liver, spleen, kidneys, mesenteric fat (fat associated with the intestines), and omental fat. The small intestine was separated from the mesentery, and its length was measured. Any contents of these tissues were removed, and the tissues were then rinsed clean with cold water and allowed to drip dry before weighing. For cows pregnant at slaughter, the weight of the calf was determined. The carcass and all tissues dissected were incinerated as dictated by Intervention Board procedures for cohort culls.

As soon as the rumen was removed, a 2.54- $\times 2.54-$ $\mathrm{cm}$ section of rumen was excised from the ventral floor of the cranial sac, washed with $0.9 \%$ (wt/vol) $\mathrm{NaCl}$ solution, and weighed. Each papilla was then cut from the epithelium and transferred to $\mathrm{NaCl}$ solution. After all papillae were removed, the remaining "base" tissue was weighed and the weight of the papillae calculated by difference. The papillae were then transferred onto a measured grid and photographed. Photographs were digitally analyzed (National Institutes of Health Image Analysis Program, zippy.nimh.nih.gov, part number PB95-500195GEI) for total number, average length and width, and average and total 2-dimensional surface area.

Statistical analyses. On average ( \pm SEM), samples were obtained at $21.2 \pm 0.6$ and $7.2 \pm 0.6 \mathrm{~d}$ before ECD and $10.1 \pm 0.6$ and $22 \pm 0.7 \mathrm{~d}$ after calving. Because of scheduling problems, the final distribution of cows slaughtered at $-21,-7,10$, and 22 d relative to ECD or calving were $10,9,7$, and 10 cows, respectively. For d 7 postpartum, the distribution of cows slaughtered on each treatment were 2,2 , and 3 cows for control, supplemental barley, and supplemental protein, respectively. Otherwise, $\mathrm{n}=3$ for each diet at each time point, except that $\mathrm{n}=4$ for the control diet at $22 \mathrm{~d}$ postpartum and for the supplemental protein diet at $21 \mathrm{~d}$ before ECD. Data were analyzed statistically using the GLM procedure of SAS (2001) and a model testing the effects of day relative to expected or actual calving date, treatment (diet), and treatment $\times$ day interaction, with initial BW at the start of the study included as a covariate. Measurements of rumen papillae mass and size were not affected by initial BW, and it was not included as a covariate in the statistical analysis of those data. Although the comparisons were not orthogonal, contrasts 
were used to compare least squares means for the control diet with least squares means for each of the treatment diets in order to aid interpretation of diet effects. For effects of day relative to calving, orthogonal contrasts were used to make the following comparisons of least squares means: before vs. after calving, $d-21$ vs. $d-7$, and $d 10$ vs. $d 21$. Final BCS and BW were analyzed using their initial value as a covariate. There were no interactions between treatment and day relative to calving $(P>0.10)$, therefore interaction means are not presented.

\section{Rumen Volume Study}

Cows, diets, and treatments. All procedures used were licensed and regulated by the UK Home Office under the Animals (Scientific Procedures) Act of 1986. Ten Holstein $\times$ British Friesian cows with rumen and duodenal cannulas established before a previous lactation and approaching at least their third lactation were used. Cows were housed in tie stalls using neck collars and had continuous access to fresh water and trace mineralized salt blocks, but salt blocks were removed at the start of the study to avoid potential effects on water intake and rumen kinetics. Beginning 6 wk before calving, cows were fed a basal gestation ration (Table 2) to meet $\mathrm{ME}$ and $\mathrm{CP}$ requirements for maintenance and gestation as described in the visceral mass study. At the start of the study they were randomly assigned to one of 2 treatments: the basal gestation ration with no supplement (control) or $1 \mathrm{~kg}$ of barley meal DM/d. Barley meal (119 g of CP, $25 \mathrm{~g}$ of ash, 25 $\mathrm{g}$ of ether extract, $118 \mathrm{~g}$ of NDF, and $626 \mathrm{~g}$ of starch/ $\mathrm{kg}$ DM) was mixed into the basal TMR. Daily rations were fed as 3 equal meals offered at 0830,1630 , and $2200 \mathrm{~h}$. Cows were moved to straw-bedded box stalls when calving appeared imminent and returned to tie stalls as soon as possible after calving. Cows were offered $2 \mathrm{~kg}$ DM per day of a lactation TMR (Table 2) beginning $9 \mathrm{~d}$ before ECD. After calving, barley supplementation ended and lactation TMR was fed for ad libitum intake. Cows were milked at approximately 600 and $1700 \mathrm{~h}$ and weighed weekly. Milk composition was measured thrice weekly as described previously (Reynolds et al., 2003).

Rumen dosing and sampling. Measurements of rumen DM and liquid volume and liquid dilution rate were made approximately 20 and $10 \mathrm{~d}$ before ECD and 10,20 , and $30 \mathrm{~d}$ after calving. This process was similar to that described by Gasa et al. (1991) and based on the concept for using 2 markers, which are pulse dosed at different time points, as proposed by France et al. (1991). The day relative to calving on which sampling occurred varied with actual calving date and on average
Table 2. Composition of the TMR fed during gestation and lactation in the rumen volume study.

\begin{tabular}{lcc}
\hline Composition & Gestation & Lactation \\
\hline Ingredient, g/kg DM & & \\
Chopped barley straw & 250 & \\
Maize silage & 150 & 350 \\
Grass silage & 450 & 150 \\
Soybean meal, 54\% CP & 60 & 150 \\
Dry rolled barley & 80 & \\
Dry rolled wheat & & 105 \\
Rapeseed meal & & 75 \\
Ground corn & & 50 \\
Molassed sugar beet shreds & & 50 \\
Wheat mids & & 49 \\
Fat (Megalac) & $10^{1}$ & 10 \\
Mineral mix & & $11^{2}$ \\
Composition & 445 & \\
DM, g/kg as fed & 2.34 & 476 \\
Estimated ME ${ }^{3}$, Mcal/kg DM & 118 & 2.89 \\
CP & 526 & 186 \\
NDF & 34 & 325 \\
Ether extract & 80 & 71 \\
Ash & 98 & 241 \\
Starch & 31 & 57 \\
Sugars & 242 & 376 \\
Nonfiber carbohydrate & \\
\hline
\end{tabular}

${ }^{1}$ Containing (per kg) $138 \mathrm{~g}$ of sodium, $100 \mathrm{~g}$ of phosphorus, $100 \mathrm{~g}$ of magnesium, $15 \mathrm{~g}$ of calcium, $4.5 \mathrm{~g}$ of manganese, $2.5 \mathrm{~g}$ of zinc, 1.5 $\mathrm{g}$ of copper, $300 \mathrm{mg}$ of iodine, $100 \mathrm{mg}$ of cobalt, $15 \mathrm{mg}$ of selenium, $250 \mathrm{IU}$ of vitamin $\mathrm{E}, 60,000 \mathrm{IU}$ of vitamin D3, and 300,000 IU of vitamin $\mathrm{A}$.

${ }^{2}$ Containing (per kg) $270 \mathrm{~g}$ of calcium, $60 \mathrm{~g}$ of magnesium, $40 \mathrm{~g}$ of phosphorus, $40 \mathrm{~g}$ of sodium, $5 \mathrm{~g}$ of zinc, $4 \mathrm{~g}$ of manganese, $1.5 \mathrm{~g}$ of copper, $500 \mathrm{mg}$ of iodine, $50 \mathrm{mg}$ of cobalt, $15 \mathrm{mg}$ of selenium, $500 \mathrm{IU}$ of vitamin E, 100,000 IU of vitamin D3, and 500,000 IU of vitamin A.

${ }^{3} \mathrm{ME}=$ Metabolizable energy.

${ }^{4}$ Vincini et al., 2003.

$( \pm$ SEM) measurements were made on $17.3 \pm 1.1$ and $7.7 \pm 1.3 \mathrm{~d}$ before calving and $10.2 \pm 0.4,20.2 \pm 0.4$, and $31 \pm 0.7 \mathrm{~d}$ after calving. For each sampling time, rumen samples were taken as a core sample from the digesta surface to the floor of the rumen to give approximately $12 \mathrm{~kg}$ of thoroughly mixed sample, which was then subsampled, and the sample not retained was returned to the rumen. One subsample was added to a composite sample, which was stored in a sealed container at $2^{\circ} \mathrm{C}$ until sampling was completed. The other subsample was squeezed to yield rumen fluid. These individual samples of rumen fluid were then acidified with $10 \mathrm{M}$ sulphuric acid and stored at $-20^{\circ} \mathrm{C}$. After obtaining a background sample, a solution of CrEDTA or CoEDTA diluted in distilled water was added to the rumen by injection into discrete locations and mixed as thoroughly as possible. Target doses of CrEDTA and CoEDTA (1.55 and $1.37 \mathrm{~g} / \mathrm{kg}$ daily DMI, respectively) were achieved by adding variable volumes of marker solution $(54.3[\mathrm{Cr}]$ or $47.5[\mathrm{Co}] \mathrm{mL} / \mathrm{kg}$ daily $\mathrm{DMI})$ prepared at fixed concentrations (3500 or $4000 \mathrm{ppm}$ for $\mathrm{Cr}$ 
Table 3. Main effect of supplementing the transition diet with barley or protein on rumen papillae characteristics of transition dairy cows.

\begin{tabular}{|c|c|c|c|c|c|c|c|}
\hline & \multicolumn{3}{|c|}{ Treatment } & \multirow[b]{2}{*}{ SEM } & \multirow[b]{2}{*}{$P \leq$} & \multicolumn{2}{|c|}{ Contrasts $P<1$} \\
\hline & Control & Barley & Protein & & & C vs. B & C vs. $\mathrm{P}$ \\
\hline $\mathrm{n}$ & 12 & 11 & 13 & & & & \\
\hline Total tissue weight, $\mathrm{g} / \mathrm{cm}^{2}$ & 1.113 & 1.226 & 1.124 & 0.078 & 0.54 & 0.33 & 0.93 \\
\hline \multicolumn{8}{|l|}{ Papillae } \\
\hline Weight, $\mathrm{g} / \mathrm{cm}^{2}$ & 0.515 & 0.516 & 0.443 & 0.040 & 0.35 & 0.99 & 0.23 \\
\hline Number/cm ${ }^{2}$ & 28.9 & 36.6 & 29.7 & 2.7 & 0.13 & 0.07 & 0.84 \\
\hline Average length, $\mathrm{mm}$ & 8.4 & 6.1 & 8.7 & 1.1 & 0.22 & 0.17 & 0.85 \\
\hline Average width, mm & 3.1 & 1.8 & 2.1 & 0.3 & 0.006 & 0.002 & 0.02 \\
\hline Average surface, $\mathrm{mm}^{2}$ & 22.9 & 9.0 & 15.4 & 3.6 & 0.05 & 0.02 & 0.15 \\
\hline Total surface, $\mathrm{mm}^{2} / \mathrm{cm}^{2}$ & 614.4 & 324.5 & 486.9 & 122.0 & 0.29 & 0.12 & 0.47 \\
\hline Base tissue weight, $\mathrm{g} / \mathrm{cm}^{2}$ & 0.583 & 0.710 & 0.680 & 0.062 & 0.36 & 0.18 & 0.28 \\
\hline
\end{tabular}

${ }^{1}$ Nonorthogonal comparisons of control vs. barley (C vs. B) and control vs. protein (C vs. P) supplements.

and Co, respectively). Solutions added to the rumen were analyzed for $\mathrm{Cr}$ and Co concentration to determine the dosage achieved. One marker was introduced $1 \mathrm{~h}$ before feeding at $0830 \mathrm{~h}$, and one marker was introduced $1 \mathrm{~h}$ after feeding. Samples of rumen contents were obtained before the second marker was introduced, and at approximately 1.5-h intervals until 9 additional samples were obtained.

Sample analysis. Bulked samples of rumen contents for each sampling were analyzed for DM content as soon as sampling was completed. Individual samples of rumen fluid were stored frozen until later analysis for Co and Cr concentrations (Gasa et al., 1991; Abdalla et al., 1999). The DM content of feed and refusals and DMI were measured daily throughout the study. Daily feed samples were immediately frozen and composited weekly. Weekly feed samples were dried at $60^{\circ} \mathrm{C}$, ground, and analyzed as described previously (Benson et al., 2001).
Calculations. Fractional clearance of the marker $(\mathrm{k}, \% / \mathrm{h})$ was estimated as the linear slope of the natural log concentrations of Co or Cr over time after dosing (Gasa et al., 1991). This clearance of the marker from the rumen was assumed to represent liquid dilution rate. Rumen liquid volume was calculated as the average intercept for these 2 regressions. Average rumen $\mathrm{DM}$ volume was estimated using the DM concentration of the composite sample and average rumen liquid volume. Total rumen volume was estimated as the sum of rumen liquid and DM volume.

Statistical analyses. Measurements obtained using the 2 markers were averaged and analyzed statistically as repeated measures using the Mixed Procedure of SAS (2001). Effects of gestation ration, day relative to calving, and their interaction were tested using either a compound symmetry or spatial power covariance structure, depending on the goodness of fit (Littell et al., 1996). In addition, orthogonal contrasts were used to

Table 4. Main effect of transition on DMI, milk yield, BW, and rumen papillae characteristics of dairy cows.

\begin{tabular}{|c|c|c|c|c|c|c|c|c|c|}
\hline & \multicolumn{4}{|c|}{ Day relative to calving } & SEM & $P \leq$ & \multicolumn{3}{|c|}{ Contrasts $^{1}$} \\
\hline $\mathrm{n}$ & 10 & 9 & 7 & 10 & & & & & \\
\hline Milk yield, kg/d & - & - & 26.08 & 31.88 & 1.55 & 0.04 & - & - & 0.04 \\
\hline BW before transport, $\mathrm{kg}$ & 675.8 & 685.2 & 599.9 & 600.0 & 8.4 & 0.001 & 0.001 & 0.40 & 0.99 \\
\hline BW before slaughter, $\mathrm{kg}$ & 635.8 & 654.4 & 570.1 & 548.7 & 10.0 & 0.001 & 0.001 & 0.16 & 0.20 \\
\hline \multicolumn{10}{|l|}{ Papillae } \\
\hline Weight, $\mathrm{g} / \mathrm{cm}^{2}$ & 0.389 & 0.440 & 0.527 & 0.609 & 0.048 & 0.02 & 0.004 & 0.45 & 0.25 \\
\hline Number/cm ${ }^{2}$ & 31.0 & 36.9 & 32.5 & 26.6 & 3.2 & 0.15 & 0.18 & 0.20 & 0.22 \\
\hline Average length, mm & 8.3 & 7.6 & 6.4 & 8.6 & 1.3 & 0.64 & 0.73 & 0.69 & 0.24 \\
\hline Average width, mm & 2.5 & 2.1 & 2.1 & 2.5 & 0.3 & 0.67 & 0.96 & 0.32 & 0.48 \\
\hline Average surface, $\mathrm{mm}^{2}$ & 17.8 & 14.2 & 14.0 & 17.0 & 4.1 & 0.89 & 0.91 & 0.54 & 0.62 \\
\hline Total surface, $\mathrm{mm}^{2} / \mathrm{cm}^{2}$ & 528.9 & 504.5 & 344.7 & 522.9 & 140.7 & 0.80 & 0.57 & 0.91 & 0.39 \\
\hline
\end{tabular}

${ }^{1}$ Gestation vs. lactation. 
compare measurements obtained before and after calving (d 17 and 8 before calving vs. d 10, 20, and 31 after calving), on d 17 vs. 8 before calving, on d 10 vs. 20 and 31 after calving, and on d 20 vs. 31 after calving. Weekly averages of milk fat and protein composition during the lactation phase were analyzed using either a compound symmetry or autoregressive covariance structure. As in the visceral mass study, there were no interactions $(P>0.20)$ between diet fed during gestation and day relative to calving, therefore interaction means are not presented and observations from cows on different gestation diets are averaged for each time point over the transition period, and vice versa.

\section{RESULTS}

\section{Visceral Mass Study}

Supplemental barley and protein in late gestation. There were no effects $(P>0.05)$ of supplements fed in late gestation on average BW, DMI, or milk yield, but BCS was higher in cows fed supplemental barley $(P<0.02)$ or protein $(P<0.01)$ compared with the unsupplemented control $(2.78,3.13$, and 3.19 , respectively; SEM = 0.01). The total mass of rumen papillae excised from the floor of the cranial sac was not affected by transition supplements (Table 3), but the number tended to be greater $(P<0.07)$ when barley was fed, and this was associated with a marked reduction in average width $(P<0.002)$ and average surface area $(P$ $<0.02$ ), as well as a nonsignficant reduction in length. Papillae of cows fed supplemental protein before calving also had a lower average width $(P<0.02)$ than control cows, but their average surface area only tended $(P<$ 0.15 ) to be reduced. Overall there were no effects of late gestation supplements on the weights of other visceral tissues, but in cows fed barley the total stomach tissue weight (reticulo-rumen, omasum, and abomasum) tended to be lower (20.43 vs. $22.28 \mathrm{~kg}, \mathrm{SEM}=0.38 ; P$ $<0.06)$ and mesenteric fat weight tended to be greater (5.94 vs. $4.92 \mathrm{~kg}, \mathrm{SEM}=0.38 ; P<0.09)$ than in control cows.

Effects oftransition. Dry matter intake was greater in early lactation (Table 4), but there was little increase in total DMI at $10 \mathrm{~d}$ postpartum. After calving BW ( $P$ $<0.001)$ was lower and BCS $(P<0.07)$ tended to be lower than during late gestation (Table 4), whereas BCS was greater in cows slaughtered closer to calving both before $(P<0.05)$ and after $(P<0.03)$ calving. There was little effect of transition on the 2-dimensional size of rumen papillae (Table 4). However, compared with measurements from gestating cows, their total mass was increased in lactating cows $(P<0.004)$, and the mass of the tissue they were excised from was decreased $(P<0.02)$, thus total tissue weight was not affected $(P$
$>0.68)$. These changes were apparent by d 10 postpartum. The weight of the reticulo-rumen $(P<0.02)$, small intestine $(P<0.002)$, large intestine $(P<0.06)$, and liver $(P<0.10)$ were, or tended to be, greater after calving (Table 5), whereas the weight of the spleen $(P$ $<0.10)$, mesenteric fat $(P<0.04)$ and total (mesenteric plus omental) fat $(P<0.08)$ were, or tended to be, reduced. For the reticulo-rumen, intestines, and liver increases after calving were minimal until $21 \mathrm{~d}$ postpartum, when their mass was greater than at $10 \mathrm{~d}$ postpartum. Apart from a reduction in the weight of the small intestine at $\mathrm{d} 7$ compared with $\mathrm{d} 21$ prepartum $(P<$ 0.02 ), there were no significant changes in visceral tissue mass between measurements made at 21 and 7 d prepartum.

\section{Rumen Volume Study}

There were no effects of supplemental barley on DMI (Figure 1), rumen DM, or liquid volume, but the liquid dilution rate $(P<0.11)$ tended to be greater in cows fed the control ration $(17.3$ vs. $15.2 \pm 0.8 \% / \mathrm{h})$. This was associated with numerically higher $(P<0.13)$ milk yield in those cows (Figure 1; 42.7 vs. $38.6 \pm 1.8 \mathrm{~kg} / \mathrm{d}$ ). Milk fat composition tended to be lower in control cows $(P<$ $0.08 ; 39.3$ vs. $46.0 \pm 2.3 \mathrm{~g} / \mathrm{kg}$ ), but milk protein composition was not affected by gestation ration. Intake of DM increased after calving $(P<0.001)$, and the increases were evident by d 10 postpartum (Table 6). This increase in DMI was associated with increases in rumen DM $(P<0.001)$ fill. Rumen total digesta and liquid volume was not different between gestation and lactation measurements, but was, or tended to be, lower at d 10 postpartum than for subsequent measurements during lactation $(P<0.05$ and 0.06 , respectively). Liquid dilution rate was greater in lactating cows than before they calved $(P<0.008)$ and tended to be lower $(P<0.07)$ at $31 \mathrm{~d}$ postpartum than $20 \mathrm{~d}$ postpartum.

\section{DISCUSSION}

\section{Visceral Mass Study}

Numerous studies in sheep have shown positive effects of increased diet intake on gut tissue and liver mass (e.g., Ferrell, 1988; McLeod and Baldwin, 2000) and similar effects have been reported in nonlactating cattle (Johnson et al., 1990; Sainz and Bentley, 1997). To date, we are aware of only a limited number of direct measurements of differences in visceral tissue mass between dry and lactating dairy cows (Smith and Baldwin, 1974; Andrew et al., 1994). In the most comprehensive tissue dissection study conducted in dairy cattle to date, measurements of body composition and tissue mass were made in early lactation (immediately after 
Table 5. Main effect of transition on weights of various tissues in dairy cows after covariate adjustment for initial BW.

\begin{tabular}{|c|c|c|c|c|c|c|c|c|c|}
\hline & \multicolumn{4}{|c|}{ Day relative to calving } & SEM & $P \leq$ & \multicolumn{3}{|c|}{ Contrasts $^{1}$} \\
\hline $\mathrm{n}$ & 10 & 9 & 7 & 10 & & & & & \\
\hline Omasum, kg & 6.26 & 6.09 & 5.99 & 6.63 & 0.30 & 0.55 & 0.67 & 0.68 & 0.19 \\
\hline Abomasum, kg & 2.78 & 2.60 & 2.96 & 3.15 & 0.17 & 0.17 & 0.06 & 0.45 & 0.48 \\
\hline Total stomach, $\mathrm{kg}$ & 21.32 & 20.44 & 21.35 & 22.21 & 0.70 & 0.43 & 0.23 & 0.33 & 0.45 \\
\hline S. Intestine, $\mathrm{kg}$ & 8.87 & 8.06 & 8.55 & 9.54 & 0.23 & 0.002 & 0.03 & 0.02 & 0.008 \\
\hline Caecum, g & 504 & 480 & 492 & 523 & 23 & 0.58 & 0.52 & 0.45 & 0.37 \\
\hline Liver, kg & 9.00 & 8.80 & 8.83 & 9.59 & 0.25 & 0.10 & 0.24 & 0.56 & 0.05 \\
\hline Spleen, g & 1027 & 1050 & 940 & 836 & 65 & 0.10 & 0.04 & 0.80 & 0.29 \\
\hline Kidney, g & 1485 & 1560 & 1619 & 1632 & 53 & 0.19 & 0.08 & 0.31 & 0.88 \\
\hline Mesenteric fat, $\mathrm{kg}$ & 6.18 & 5.68 & 5.08 & 4.25 & 0.42 & 0.04 & 0.009 & 0.35 & 0.24 \\
\hline Omental fat, $\mathrm{kg}$ & 10.90 & 12.36 & 10.87 & 9.28 & 1.16 & 0.40 & 0.21 & 0.33 & 0.41 \\
\hline Total fat, kg & 16.84 & 17.78 & 15.72 & 12.67 & 1.42 & 0.08 & 0.05 & 0.64 & 0.16 \\
\hline
\end{tabular}

${ }^{1}$ Gestation vs. lactation.

calving and 2, 5, and 8 wk postpartum) and then at 3to 4 -wk intervals to 29 wk postpartum, but no measurements were made during late pregnancy (Gibb et al., 1992). However, Scheaffer et al. (2001) observed no changes in gastrointestinal tract or liver tissue mass during pregnancy of beef cattle. In the present and all of these previous studies, there was no evidence of changes in gut or liver tissue mass that were independent of changes in ration DMI. In fact, cows in the present study exhibited poor transition to their lactation ration, which was high in rumen digestible nonfiber carbohydrates. Thus although the ME and CP intakes

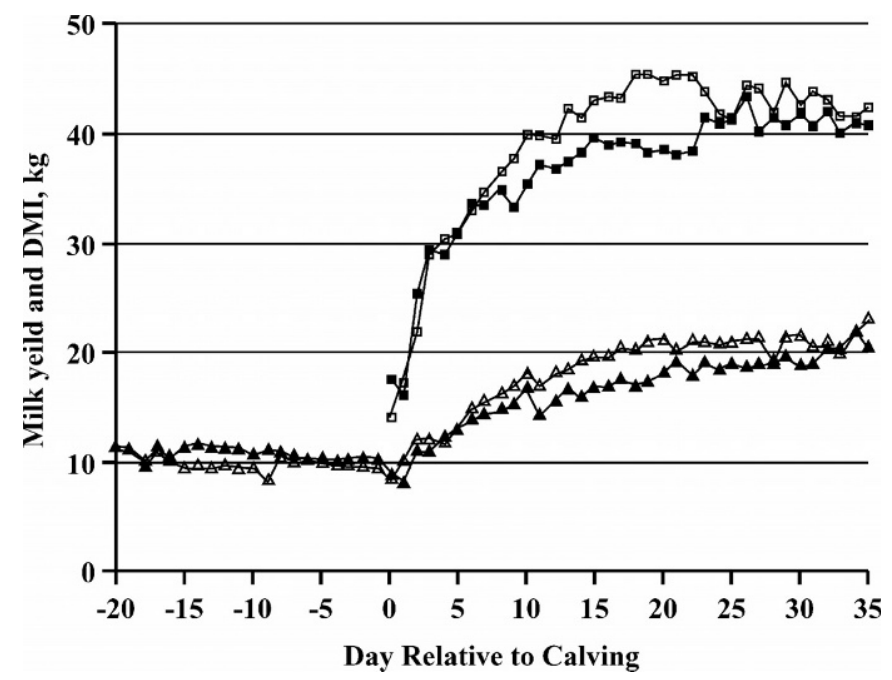

Figure 1. DMI ( $\triangle$ and $\boldsymbol{\Delta}$ ) and milk yield ( $\square$ and $\mathbf{\square}$ ) in transition dairy cows fed a control ration (open symbols) or supplemental barley (solid symbols) beginning 6 wk before expected calving date (rumen volume study). of cows slaughtered at $10 \mathrm{~d}$ after calving were increased through changes in ration composition, their DMI had not increased relative to cows slaughtered at 17 or $8 \mathrm{~d}$ prepartum. Although not an intended outcome, it reinforces the concept that changes in gut and liver mass during transition are largely determined by DMI and nutrient supply. There was no evidence of changes in visceral tissue mass before calving, except for a decrease in small intestinal mass at $8 \mathrm{~d}$ compared with $17 \mathrm{~d}$ before calving, and little change in digestive tissue or liver mass at d 10 postpartum. For the reticulo-rumen, small intestine, large intestine, and liver, increases in mass were not evident until d 21 postpartum, when DMI had increased. However, our data do not address possible changes in tissue composition or functional morphology (Scheaffer et al., 2001). We had intended to make additional measurements of tissue composition, but most unfortunately Intervention Board policy did not allow the removal of nonneural tissue samples from the abattoir for research purposes.

Changes in the mass of some tissues after calving were measured by $\mathrm{d} 10$ of lactation. The mass of rumen papillae were increased at $10 \mathrm{~d}$ postpartum, but this likely reflects the increased concentrate content of the ration and increased VFA absorption (Fell and Weekes, 1975). In addition, the mass of the kidneys tended to be greater after calving, perhaps to facilitate greater removal of urea and other waste products (Reynolds et al., 2003), as well as increased water intake and turnover. The kidneys are also a site of glucose synthesis, thus an increase in kidney mass could enable greater glucose supply to support milk synthesis. The weight of mesenteric fat was reduced after calving, which must reflect increased mobilization of body fat to support 
Table 6. Main effect of day relative to calving on rumen fill characteristics, DMI, and milk yield.

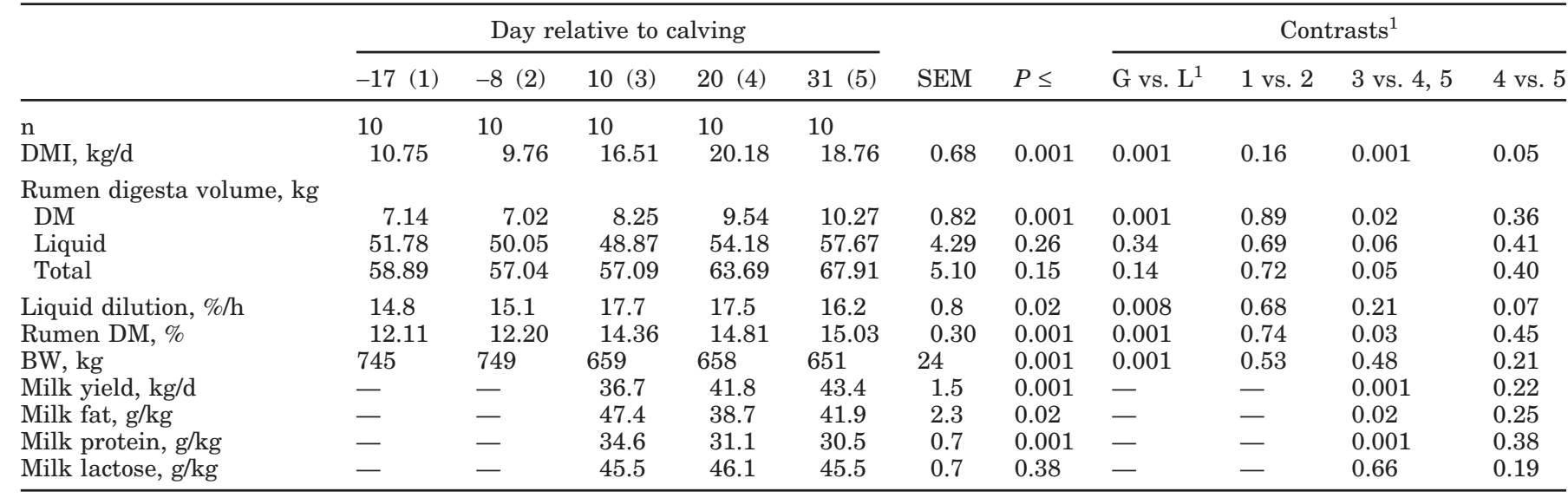

${ }^{1}$ Gestation vs. lactation.

milk energy output. In the study of Gibb et al. (1992), mesenteric fat was reduced by over $2 \mathrm{~kg}$ in the first 2 wk of lactation, compared with a loss of 1.5 and $3.1 \mathrm{~kg}$ at 10 and $21 \mathrm{~d}$ postpartum in the present study. We also observed a significant decrease in the weight of the spleen after calving, which may reflect an increase in blood volume to enable increased blood flow after calving (Reynolds et al., 2003).

There were relatively few effects of supplemental barley or rumen-protected protein on visceral mass in the present study, and there were no positive effects of these same gestation rations on DMI or milk production in a companion lactation trial (Pushpakumara et al., 2002). A popular premise has been that increased liver protein synthesis in late gestation (Bell, 1995) is indicative of increased amino acid requirements of late lactation cows generally. In the present study, however, there were no increases in visceral tissue mass during the last 17 to $8 \mathrm{~d}$ of prepartum. Similarly, data from the present study show little benefit of supplemental barley in late gestation for visceral tissue mass. Indeed, cows fed barley in gestation had reduced total stomach mass. Feeding barley did increase mesenteric fat mass, which likely reflects greater ME intake in late gestation. However, this response was not manifested when a similar amount of ME was supplied as rumen protected protein and may reflect a specific effect of supplemented barley on VFA absorption or glucose availability.

In the present study, cows fed supplemental barley in late gestation had less average rumen papillae surface area, not more. This likely reflects the fact that cows assigned to the barley diet had more total papillae due to genetic or previous environmental influences, thus the papillae present were by nature narrower and shorter. Andersen et al. (1999) also observed no positive effect of substituting forage with $4 \mathrm{~kg}$ of barley in isoen- ergetic diets fed in late gestation on rumen papillae. Similarly, Ingvartsen et al. (2001) reported that in a companion study the same transition diet had no effect on DMI or BW, and it reduced milk yield. These data suggest little benefit of substituting concentrates for forages with the intention of increasing the absorptive capacity of rumen papillae. Although Dirksen et al. (1985) observed an increased papillae surface area when cows were switched from a straw-based dry cow ration to a high concentrate lactation ration, this represented a massive change in both ration composition and total energy intake. Cows fed supplemental protein had narrower papillae than cows fed the control diet, but this again may simply reflect genetic or environmental influences unaccounted for in our assignment of cows to treatments. We observed variation from cow to cow, and within the same cow, in the size and shape of the papillae present. An example is shown in Figure 2, which illustrates the extreme variation in number and shape of papillae we observed between cows fed the same diets and harvested at the same stage of lactation. Based on the variation we observed, measurements of papillae morphology should not be based on samples of a limited number of papillae from a limited number of cows.

It has been noted that the number of papillae per unit surface area of the rumen declines as virtually all wild and domestic ruminants mature and increase in size. This has been attributed to growth of the rumen with greater age and intake, which stretches the basal epithelial tissue and "spaces out" the papillae present (Hoffman, 1973). In line with this observation, there was a trend (Table 4) for a decrease in papillae number in cows slaughtered after calving in the present study. Although there was no difference in the 2-dimensional surface area of rumen papillae as cows progressed 

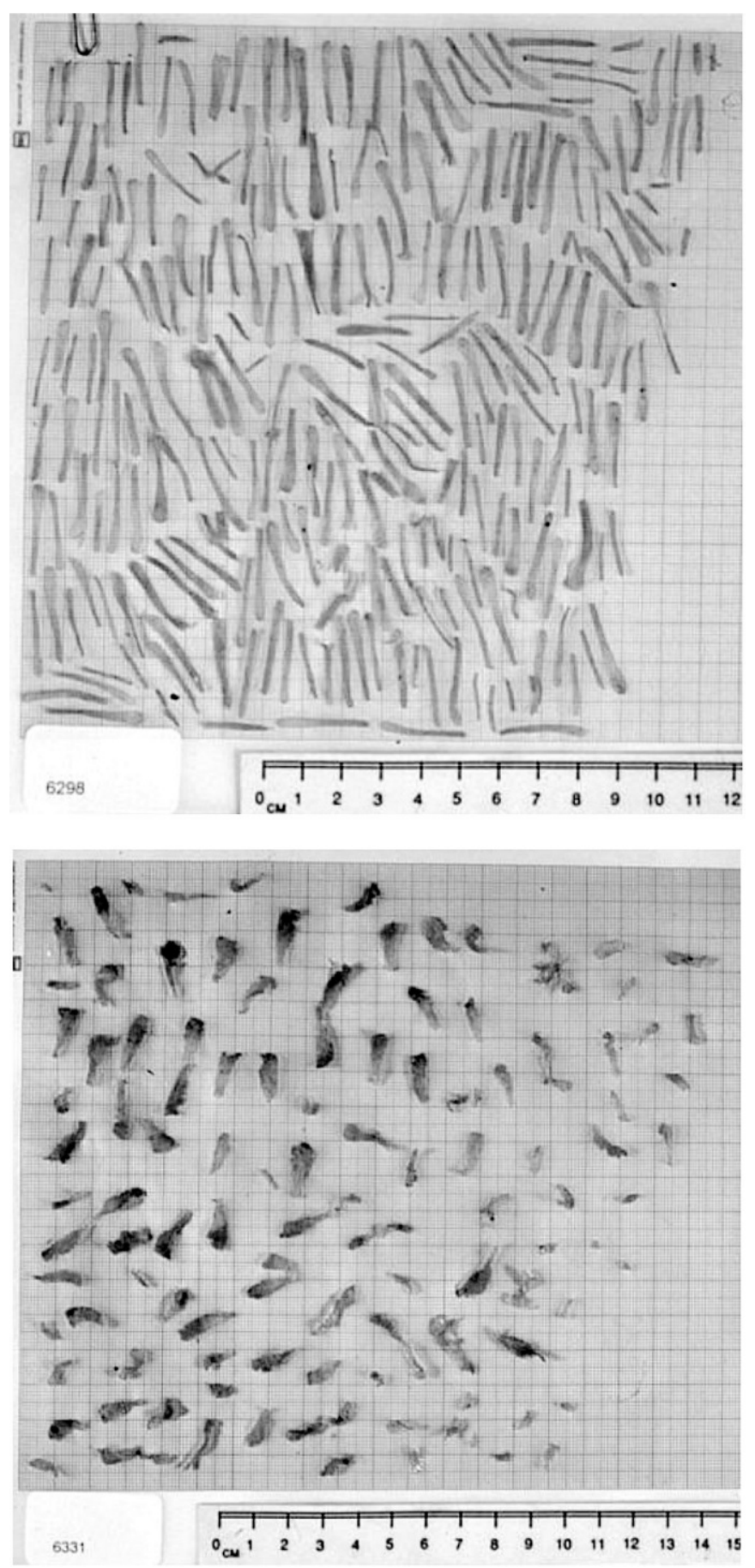

Figure 2. Papillae removed from a $2.54-\mathrm{cm}^{2}$ section of the floor of the cranial sac of the rumen of 2 cows fed barley before calving and slaughtered at 23 or $19 \mathrm{~d}$ postpartum.

through transition, papillae mass increased after calving. This likely reflects changes in the thickness of the papillae and their vascularity, which was not measured in our study but would enhance their absorptive capacity. Increases in papillae mass after calving may well have been driven by increased VFA absorption, as the VFA and n-butyrate, in particular, have hypertrophic effects on rumen papillae (Sander et al., 1959; Dirksen et al., 1985). Decreases in the mass of the rumen tissue from which the papillae were removed may reflect losses of intramuscular and subserosal lipid, or it may reflect stretching of the basal epithelial tissue and musculature. Our data suggest that it is not simply the 2-dimensional surface area of papillae that adapts to increased nutrient intake in early lactation, but the 3-dimensional structure and total mass increases to facilitate increased organic acid absorption.

\section{Rumen Volume Study}

The original mathematical approach suggested by France et al. (1991) for the estimation of rumen volume from 2 markers added to the rumen at separate time points gave nonsensical results unless an average clearance rate was derived independently and used at each time point to estimate rumen volume. These estimates were quite variable; therefore, for the present report we chose not to use the 2-marker model as proposed by France et al. (1991). However, we were able to derive 2 "independent" estimates of rumen liquid volume and turnover, which on the whole agreed extremely well and were comparable to other measurements for dry and lactating dairy cows (Gasa et al., 1991; Dann et al., 1999).

In contrast to the results of Dann et al. (1999), rumen liquid turnover, but not volume, increased after calving in our study. In the present study there was a numerical increase in rumen liquid volume at $\mathrm{d} 20$ and 31 compared with measurements before calving, but liquid volume had not changed by d 10 after calving. Dann et al. (1999) reported a numerical increase of $16 \mathrm{~kg}$ between $\mathrm{d} 9$ to 17 prepartum and d 23 to 26 postpartum, which did not appear to be significant, but no change in liquid turnover. In our study, the increase in liquid dilution observed may have been attributable to increased water consumption to support milk yield. This would also explain the trend towards decreased liquid dilution rate in cows fed supplemental barley, as their milk yield tended to be lower.

Rumen DM volume increased after calving, but had only increased by $3.25 \mathrm{~kg}$ at $31 \mathrm{~d}$ postpartum, whereas DMI had increased by $9 \mathrm{~kg} / \mathrm{d}$. As liquid volume was not affected, this increase in DM volume was attributable to an increase in the DM concentration of rumen liquid, and it implies that in early lactation increased DMI is associated with greater gut fill without an associated increase in rumen volume per se. 


\section{CONCLUSIONS}

In transition dairy cows, increased mass of the gastrointestinal tract tissues and liver appear to be dictated by DMI and nutrient supply and not a response directed by lactogenic hormones, independent of changes in intake, as proposed previously. We did observe an increase in the mass, but not the surface area, of cranial sac rumen papillae at $d 10$ postpartum, before DMI had increased, but this could be attributed to the change to the high concentrate lactation ration after calving. We observed large variations in the number and shape of rumen papillae between cows, suggesting that large numbers of papillae and cows should be sampled for studies of papillae morphology. Rumen DM volume and liquid dilution rate were increased after calving but not rumen liquid volume. This likely reflects increases in $\mathrm{DM}$ and water intake without immediate increases in rumen capacity. Finally, other than a slight increase in BCS, we did not observe any effects of supplemental barley or rumen-protected protein in the last $6 \mathrm{wk}$ of gestation that support their use as supplements in late gestation rations of dairy cows. Feeding supplemental barley increased mesenteric fat but reduced stomach mass, whereas feeding rumen-protected protein had no beneficial effects on visceral tissue mass.

\section{ACKNOWLEDGMENTS}

These studies were funded by the Milk Development Council of England, Scotland and Wales. The dedicated support and contributions of Lynfa Harris, Andrew Hattan, Debbie Cockman, Colin Green, Barney Jones, and CEDAR technical staff in the collection and processing of samples and the daily management and care of cows are gratefully acknowledged. We would also like to acknowledge the services and assistance of staff at the University of Bristol, Langford, UK; including Jeff Wood and Dave Brock of the Division of Food Animal Science, and Norman Lee, Robert Brafield, Simon Leader, Bruce Golledge, and The Photographic Unit of the School of Veterinary Science. We would also like to thank Colin Dawson and J. F. V. Vincent of The University of Reading Centre of Biomimetics for the use of their digital analysis facilities. The advice and detailed dissection protocols shared by Malcolm Gibb of The Institute of Grassland and Environmental Research, North Wyke, Devon were invaluable and greatly appreciated. Finally, we express our sincere appreciation to the UK Meat and Livestock Commission, Meat Hygiene Service and Intervention Board for allowing the use of cohort cows for the conduct of this study.

\section{REFERENCES}

Abdalla, A. L., J. D. Sutton, R. H. Phipps, and D. J. Humphries. 1999. Digestion in the rumen of lactating dairy cows given mixtures of urea-treated whole-crop wheat and grass silage. Anim. Sci. 69:203-212

Andersen, J. B., J. Sehested, and K. L. Ingvartsen. 1999. Effect of dry cow feeding strategy on rumen $\mathrm{pH}$, concentration of volatile fatty acids and rumen epithelium development. Acta Agric. Scand. 49:149-155.

Andrew, S. M., D. R. Waldo, and R. A. Erdman. 1994. Direct analysis of body composition of dairy cows at three physiological stages. J. Dairy Sci. 77:3022-3033.

Bauman, D. E. 2000. Regulation of nutrient partitioning during lactation: Homeostasis and homeorhesis revisited. Pages 311-327 in Ruminant Physiology: Digestion, Metabolism and Growth and Reproduction. P. J. Cronge, ed. CAB Publishing, New York, NY.

Bell, A. W. 1995. Regulation of organic nutrient metabolism during transition from late pregnancy to early lactation. J. Anim. Sci. 73:2804-2819.

Benson, J. A., C. K. Reynolds, D. J. Humphries, S. M. Rutter, and D. E. Beever. 2001. Effects of abomasal infusion of long chain fatty acids on intake, feeding behavior and milk production in dairy cows. J. Dairy Sci. 84:1182-1191.

Blaxter, K. L. 1944. Experiments on the use of home grown foods for milk production. II. The effect of feeding concentrated and bulky foods before calving on subsequent milk production. J. Agric. Sci. (Camb.) 34:27.

Campbell, R. M., and B. F. Fell. 1964. Gastrointestinal hypertrophy in lactation and its relation to food intake. J. Physiol. (Lond.) 171:90-97.

Dann, H. M., G. A. Varga, and D. E. Putnam. 1999. Improving energy supply to late gestation and early postpartum dairy cows. J. Dairy Sci. 82:1765-1778.

Dirksen, G. U., H. G. Liebich, and E. Mayer. 1985. Adaptive changes of the ruminal mucosa and their functional and clinical significance. Bovine Pract. 20:116.

Fell, B. F., R. M. Campbell, W. S. Mackie, and T. E. C. Weekes. 1972. Changes associated with pregnancy and lactation in some extrareproductive organs of the ewe. J. Agric. Sci. (Camb.) 79:397-407.

Fell, B. F., and T. E. C. Weekes. 1975. Food intake as a mediator of adaptation in the ruminal epithelium. Pages 101-118 in Digestion and Metabolism in the Ruminant. I. W. McDonald and A. C. I. Warner, eds. The University of New England Publishing Unit, Armidale, Australia

Ferrell, C. L. 1988. Contribution of visceral organs to animal energy expenditure. J. Anim. Sci. 66(Suppl. 3):23-34.

France, J., R. C. Siddons, M. S. Dhanoa, and J. H. M. Thornley. 1991. A unifying mathematical analysis of methods to estimate rumen volume using digesta markers and intraruminal sampling. J. Theor. Biol. 150:145-155.

Gasa, J., K. Holtenius, J. D. Sutton, M. S. Dhanoa, and D. J. Napper. 1991. Rumen fill and digesta kinetics in lactating Friesian cows given two levels of concentrates with two types of grass silage ad lib. Br. J. Nutr. 66:381-398.

Gibb, M. J., W. E. Ivings, M. S. Dhanoa, and J. D. Sutton. 1992. Changes in body components of autumn-calving HolsteinFriesian cows over the first 29 weeks of lactation. Anim. Prod. 55:339-360.

Grummer, R. R. 1995. Impact of changes in organic nutrient metabolism on feeding the transition dairy cow. J. Anim. Sci. 73:2820-2833.

Hartnell, G. F., and L. D. Satter. 1979. Determination of rumen fill, retention time and ruminal turnover rates of ingesta at different stages of lactation in dairy cows. J. Anim. Sci. 48:381-392.

Hoffman, R. R. 1973. The influence of food and feeding habits on ruminant stomach structure. Pages $38-45$ in The Ruminant Stomach. East African Monographs in Biology, Vol. 2. East African Literature Bureau, Nairobi, Kenya.

Ingvarsten, K. L., O. Aaes, and J. B. Andersen. 2001. Effects of pattern of concentrate allocation in the dry period and early lactation on feed intake and lactation performance in dairy cows. Livest. Prod. Sci. 71:207-221.

Ingvarsten, K. L., and J. B. Andersen. 2000. Integration of metabolism and intake regulation: A review focusing on periparturient animals. J. Dairy Sci. 83:1573-1597. 
Johnson, D. E., K. A. Johnson, and R. L. Baldwin. 1990. Changes in liver and gastrointestinal tract energy demands in response to physiological workload in ruminants. J. Nutr. 120:649-655.

Littell, R. C., G. A. Milliken, W. W. Stroup, and R. D. Wolfinger. 1996. SAS System for Mixed Models. SAS Institute Inc., Cary, NC.

McLeod, K. R., and R. L. Baldwin. 2000. Effects of diet forage:concentrate ratio and metabolizable energy intake on visceral organ growth and in vitro oxidative capacity of gut tissues in sheep. J. Anim. Sci. 78:760-770.

Moorby, J. M., R. J. Dewhurst, and S. Marsden. 1996. Effect of increasing digestible undegraded protein supply to dairy cows in late gestation on the yield and composition of milk during the subsequent lactation. Anim. Sci. 63:201-213.

Mulvaney, P. 1977. A condition scoring technique for use with British Friesian cows. Anim. Prod. 24:157-158.

NRC. 1989. Nutrient Requirements of Dairy Cattle. 6th Revised Edition. National Academy Press, Washington, DC.

NRC. 2001. Nutrient Requirements of Dairy Cattle. 7th Revised Edition. National Academy Press, Washington, DC.

Pushpakumara, P. G. A., N. H. Gardner, C. K. Reynolds, D. E. Beever, and D. C. Wathes. 2003. Relationships between transition period diet, metabolic parameters and fertility in lactating dairy cows. Theriogenology 60:1165-1185.

Reynolds, C. K., P. C. Aikman, B. Lupoli, D. J. Humphries, and D. E. Beever. 2003. Splanchnic metabolism of dairy cows during the transition from late gestation through early lactation. J. Dairy Sci. 86:1201-1217.

Sainz, R. D., and B. E. Bentley. 1997. Visceral organ mass and cellularity in growth-restricted and refed beef steers. J. Anim. Sci. 75:1229-1236

Sander, E. G., R. G. Warner, H. N. Harrison, and J. K. Loosli. 1959. The stimulatory effect of sodium butyrate and sodium propionate on the development of rumen mucosa in the young calf. J. Dairy Sci. 42:1600-1605.

SAS/STAT User's Guide. Version 8.2. 2001. SAS Institute Inc., Cary, NC.

Scheaffer, A. N., J. S. Caton, M. L. Bauer, and L. P. Reynolds. 2001. Influence of pregnancy on body weight, ruminal characteristics, and visceral organ mass in beef heifers. J. Anim. Sci. 79:24812490

Smith, N. E., and R. L. Baldwin. 1974. Effects of breed, pregnancy, and lactation on weight of organs and tissues in dairy cattle. J. Dairy Sci. 57:1055-1060.

VanSaun, R. J., S. C. Idleman, and C. J. Sniffen. 1993. Effect of undegradable protein amount fed prepartum on postpartum production in first lactation Holstein cows. J. Dairy Sci. 76:236-244.

Vicini, J. L., H. G. Bateman, M. K. Bhat, J. H. Clark, R. A. Erdman, R. H. Phipps, M. E. Van Amburgh, G. F. Hartnell, R. L. Hintz, and D. L. Hard. 2003. Effect of feeding supplemental fibrolytic enzymes or soluble sugars with malic acid on milk production. J. Dairy Sci. 86:576-585. 